\title{
Food antibodies in oral disease: A study of serum antibodies to food proteins in aphthous ulceration and other oral diseases
}

\author{
H. C. THOMAS ${ }^{1}$, ANNE FERGUSON, J. G. McLENNAN, AND D. K. MASON \\ From the University Department of Bacteriology and Immunology, Western Infirmary, Glasgow, and the \\ University Department of Oral Medicine, Glasgow Dental Hospital
}

SYNOPSIS We have investigated the incidence of antibodies to food antigens in patients with recurrent minor aphthous ulceration and in patients with other oral ulcerative diseases. The incidence of these antibodies was the same in both groups of patients and was significantly greater than the incidence in a control group of normal people. There was no evidence to support the hypothesis that aphthous ulceration is primarily due to hypersensitivity to food antigens. The factors which might contribute to the absorption of antigenic molecules from the mouth and to the increased immune response in patients with oral disease have been considered.

Taylor, Truelove, and Wright (1964) investigated the incidence of serum antibodies to milk proteins and gluten in patients with diseases of the gastrointestinal tract. They noted an increased incidence in patients with major aphthous ulceration of the mouth but this observation has not been pursued further. We have investigated some possible explanations of this observation: (1) the antibodies may indicate a hypersensitivity to food proteins and this may be either the primary cause of the ulceration or a secondary event causing continuation of the disease; (2) the antibodies may represent a normal response to cow's milk proteins which are being absorbed in increased amounts through a damaged mucosa. Alternatively, defective secretion of IgA class antibody may lead to increased absorption of antigens through an otherwise normal mucosa. This latter hypothesis is based on the observation that patients with IgA deficiency are more likely to develop antibodies to food antigens than people with a normal IgA system (Buckley and Dees, 1969; Huntley, Robbins, Lyerly, and Buckley, 1971).

We have studied patients with recurrent minor aphthous ulceration and patients with non-aphthous ulcerative diseases of the mouth to determine whether the increased incidence of antibodies to food antigens is peculiar to aphthous ulceration of

${ }^{1}$ Correspondence to: Dr H. C. Thomas, University Department of Bacteriology and Immunology, Western Infirmary, Glasgow, G11 6NT.

Received for publication 19 March 1973. the mouth or whether it occurs in any oral disease which involves mucosal ulceration. We examined serum specimens from these patients and a group of normal people for the presence of antibodies to a variety of food antigens.

The possibility of an abnormality of the IgA system was investigated by measuring serum immunoglobulin concentrations.

\section{Patients and Methods}

Twenty-five patients with recurrent minor aphthous ulceration of the mouth (group I) and 22 patients with other acute and chronic ulcerative lesions of the mouth (group II) were included in this investigation. All patients were taking a normal diet and were attending the Glasgow Dental Hospital as outpatients. The patients included in this study had no symptoms suggestive of gastrointestinal disease.

Table I summarizes the diagnoses of the patients

\begin{tabular}{llll}
\hline Disease & $\begin{array}{l}\text { Total No. of } \\
\text { Patients }\end{array}$ & Number on Steroids \\
\cline { 3 - 4 } & Local & Systemic \\
\hline $\begin{array}{l}\text { Acute ulcerative gingivitis } \\
\text { (Vincent's type) }\end{array}$ & 12 & & \\
$\begin{array}{l}\text { Pemphigus } \\
\text { Benign mucous membrane } \\
\text { pemphigoid }\end{array}$ & 3 & 1 & 2 \\
$\begin{array}{l}\text { Erosive lichen planus } \\
\text { Behçet's syndrome }\end{array}$ & 2 & 1 & 1 \\
\hline
\end{tabular}

Table I Oral diseases included in group II 
included in group II. Six patients in group II were receiving either local or systemic steroids; none of the patients in group I were on steroids. The age and sex distribution of the groups were approximately similar. The patients with acute ulcerative gingivitis (Vincent's type) were examined for the presence of antibody four to six weeks after the onset of the infection.

Blood specimens were obtained from the patients by venepuncture and sera were stored at $-20^{\circ} \mathrm{C}$. A control series of plasma specimens from 50 blood donors was supplied by the Western Regional Transfusion Service. The results obtained from this control group were similar to other control groups studied by the same technique (Ross, Ferguson, and Watkinson, 1972). The control groups were not screened for a history of recurrent aphthous ulceration but only $10 \%$ of the population would be expected to have the disorder at some time during their lives (Sircus, Church, and Kelleher, 1957). None of the blood donors had sufficiently severe oral disease to attend hospital.

All specimens were coded so that the results were obtained without knowledge of the diagnosis.

\section{PRECIPITIN TESTS}

Crowle's (1958) micro-gel-diffusion technique, as modified by Heiner, Lahey, Wilson, Gerrard, Shwachman, and Khaw (1962); Beckwith and Heiner (1966 was used to detect precipitating antibodies to cereal and animal protein antigens. This technique has been successfully used in a number of studies of dietary protein antibodies (Heiner et al, 1962; Holland, Hong, Davis, and West, 1962; Bayless, Partin, and Partin, 1967; Ferguson and Carswell, 1972). Immunodiffusion takes place in a $1 \mathrm{~mm}$ thick layer of agar on a microscope slide; $20 \mu \mathrm{l}$ drops of antigen and antibody are placed in holes in a perspex template lying on top of the agar. After two days the slides are washed and the precipitin lines stained with thiazine red. When dried these slides can be mounted with coverslips for permanent storage. Each specimen was tested against the 11 antigens listed below.

\section{Cereal antigens}

Wheat flour (white), gluten (British Drug Houses), oatmeal, and rice flour: aqueous extracts of these cereals were prepared as described by Heiner $e t$ al (1962) using ice-cold phosphate-buffered saline at pH $7 \cdot 2$.

\section{Animal protein antigens}

Cow's milk, bovine calf serum, sheep serum, chicken serum, pig serum, egg white, and egg yolk: cow's milk was centrifuged to remove the fat and used un- diluted and at $1 / 10$ dilution in phosphate-buffered saline. Bovine calf, sheep, pig, and chicken sera were diluted $1 / 10$ in phosphate-buffered saline. Egg white $\overrightarrow{\vec{F}}$ and egg yolk were diluted $1 / 50$ in phosphate $-\frac{-}{-}$ buffered saline, centrifuged and filtered.

QUANTITATION OF ANTIBODIES TO COW'S

MILK BY PASSIVE HAEMAGGLUTINATION

Passive haemagglutination was used to detecto antibodies to five protein constituents of cow's milk. $\overrightarrow{0}$ Formalinized human red cells were tanned and coated with antigens by the method of Boyden (1951) as described by Herbert (1967).

The tanned cells were reacted with the following? antigens at a concentration of $1 \mathrm{mg} / \mathrm{ml}$ : bovineos serum albumin (Armour), bovine gamma globulinic (Armour), alpha-lactalbumin (Koch-Light), beta- ${ }^{\omega}$ lactoglobulin (Koch-Light), and casein (alkalio을 soluble).

Serial dilutions of each serum were tested for the ability to agglutinate cells coated with the aboven antigens. The endpoint was taken as that well which showed less than $50 \%$ agglutination.

For statistical purposes a scoring system was. devised to summate the titres of antibody against the five proteins. This was done by expressing each antibody titre as a score: $<1$ in $16=$ score $0, \overline{0}$ 1 in $16=$ score 1,1 in $32=$ score 2 , etc, and $>1$ in $2048=$ score 8 .

The sum of the scores for antibody to each of the five cow's milk proteins was calculated and will be 3 referred to as the cow's milk antibody score (CMAJ score).

SERUM IMMUNOGLOBULIN CONCENTRATIONS Serum IgM, IgG, and IgA concentrations were estimated by the radial immunodiffusion technique described by Mancini et al (1965). Immunodiffusion plates were obtained from Behringwerke.

\section{Results}

Precipitins to ruminant and avian antigens weres detected in four out of 25 patients with aphthous ulceration (see table II). Precipitins to cereal or swine antigens were not detected in this group. Onlyw for avian antigens did the results significantly differ from the results of a control group (blood donors) There was no significant difference between the incidence of precipitins to food antigens in aphthous ulcer patients (group I) and the patients with otheroral diseases (group II).

The results for cow's milk antibodies (CMA) are seen in table III. As a group, the patients with aphthous ulceration had significantly higher antio body scores than the control group (blood donors) 


\begin{tabular}{|c|c|c|c|c|c|}
\hline \multirow[t]{2}{*}{ Patient Group } & \multirow[t]{2}{*}{ Total No. in Group } & \multicolumn{3}{|c|}{ No. of Patients with Positive Precipitin Tests to } & \multirow{2}{*}{$\begin{array}{l}\text { No. of Patients with Precipitin } \\
\text { Test Negative to all Antigens }\end{array}$} \\
\hline & & $\begin{array}{l}\text { Cereal } \\
\text { Antigens }\end{array}$ & $\begin{array}{l}\text { Ruminant } \\
\text { Antigens }\end{array}$ & $\begin{array}{l}\text { Avian } \\
\text { Antigens }\end{array}$ & \\
\hline $\begin{array}{l}\text { Control } \\
\text { Aphthous (group I) } \\
\text { Non-aphthous oral } \\
\text { disease (group II) }\end{array}$ & $\begin{array}{l}50 \\
25 \\
\\
22\end{array}$ & $\begin{array}{l}0 \\
0 \\
0\end{array}$ & $\begin{array}{l}1 \\
2(\mathrm{NS}) \\
1(\mathrm{NS})\end{array}$ & $\begin{array}{l}0 \\
4(\mathrm{P}<0.02) \\
4(\mathrm{P}<0.02)\end{array}$ & $\begin{array}{l}49 \\
21 \\
\\
18\end{array}$ \\
\hline
\end{tabular}

Table II Incidence of positive precipitin tests

$x^{2}$ test with Yates's correction applied.

NS = not significant

\begin{tabular}{|c|c|c|c|c|c|c|}
\hline \multirow[t]{2}{*}{ Patient Group } & \multirow[t]{2}{*}{ Total No. in Group } & \multicolumn{4}{|c|}{ CMA Score (see Text) } & \multirow{2}{*}{$\begin{array}{l}\text { Comparison of Patient Groups with } \\
\text { Control Group }(P \text { Values })^{1}\end{array}$} \\
\hline & & 0 & $1-4$ & $5-15$ & $16+$ & \\
\hline \multirow{3}{*}{$\begin{array}{l}\text { Control } \\
\text { Aphthous (group I) } \\
\text { Non-aphthous oral } \\
\text { disease (group II) }\end{array}$} & 50 & 48 & 2 & 0 & 0 & \\
\hline & 25 & 12 & 6 & 6 & 1 & $<0.002$ \\
\hline & 22 & 10 & 7 & 5 & 0 & $<0.002$ \\
\hline
\end{tabular}

Table III Incidence of antibodies to cow's milk proteins measured by passive haemagglutination

'Wilcoxon's score of ranks test applied.

Half of the patients had some antibody (ie, a titre of 1 in 16 to at least one cow's milk protein) detected by this technique, while only two out of 50 blood donors were positive. However, there is no significant difference in the incidence of cow's milk antibodies when the aphthous ulcer group is compared with the group of patients with other oral diseases.

The immunoglobulin concentrations were all within the normal range of our laboratory(table IV); there were no patients with IgA deficiency. The patients with serum antibodies to food proteins had immunoglobulin levels which did not differ significantly from the immunoglobulin levels of the patients without serum antibodies to food proteins.

\begin{tabular}{llll}
\hline Patient Group & $I g G(m g / 100 \mathrm{ml})$ & $\operatorname{IgM}(\mathrm{mg} / 100 \mathrm{ml})$ & $\operatorname{IgA}(\mathrm{mg} / 100 \mathrm{ml})$ \\
\hline Normal & & & \\
(mean \pm SD) & $1250 \pm 280$ & $143 \pm 58$ & $210 \pm 82$ \\
Aphthous ulcer & $1560 \pm 469$ & $165 \pm 86$ & $245 \pm 168$ \\
(mean \pm SD) & NS & NS & NS \\
\hline
\end{tabular}

Table IV Comparison of serum immunoglobulin levels in normal people and aphthous ulcer patients

Student's $t$ test applied

NS $=$ not significant

\section{Discussion}

We have confirmed the findings of Taylor (1964) that patients with oral aphthous ulceration have an abnormally high incidence of antibodies against milk antigens. In addition, we have demonstrated a significantly higher incidence of precipitins to other food proteins in the sera of these patients. It is possible that a patient may become sensitized to a single food antigen, and as a result of the damage to the mucosa caused by this hypersensitivity reaction, increased amounts of other food antigens may be absorbed and these may stimulate additional antibodies.

However, patients with other types of ulcerative disease affecting the mouth also show a similar pattern of antibodies to food antigens. In view of the diversity of these diseases it seems unlikely that they are all caused by primary hypersensitivity to food antigens and one is left with the suggestion that the presence of antibody to food antigens is merely an indication of increased mucosal permeability secondary to other factors.

Immunization to food antigens occurs when increased quantities of immunogenic molecules are absorbed from the gastrointestinal tract. This increased permeability may be the result of inflammation or ulceration but in view of the observation that patients with IgA deficiency are more likely to develop antibodies to food antigens than people with a normal IgA system, it is suggested that defective secretion of IgA class antibody may contribute to increased absorption of antigens through an otherwise normal mucosa. The possibility of a breakdown of local immunity was considered in these patients with oral disease, but serum IgA levels were normal. Salivary immunoglobulins were not estimated in this study but Lehner (1969a) found normal salivary IgA concentration in patients with minor aphthous 
ulceration. It therefore seems more likely that local mucosal breakdown was the cause of the increased absorption of immunogenic components of food.

It has been suggested that aphthous ulceration is an autoimmune disease (Lehner, 1969b) and Behcet's syndrome, pemphigus, and pemphigoid also show autoimmune features. These disorders are often associated with increased serum immunoglobulins (Lehner, 1969a) and it is possible that patients with autoimmune disease mount an increased immune response to normal amounts of antigen absorbed from the gastrointestinal tract. This is unlikely to be the complete explanation because we found an increased incidence of food antibodies in patients with Vincent's angina, and in these patients autoimmunity has not been incriminated. It seems more likely that local mucosal breakdown leading to absorption of increased amounts of food antigens was the cause of the increased incidence of food antibodies.

Antibodies to food antigens occur in coeliac disease and ulcerative colitis (Taylor, Thomson, Truelove, and Wright, 1961; Taylor and Truelove, 1961). In these diseases a large surface area is damaged. The oral diseases discussed in this paper result in damage to a much smaller area of mucosa but there is still sufficient absorption of antigen to cause immunization. This may be partly due to the higher concentration of undigested antigen in the mouth but also the antigens absorbed from the mouth enter the systemic circulation without first passing through the liver, where the more immunogenic components of the food protein might be removed (Thomas, 1973).

We wish to thank Professor R. G. White for help and advice in the preparation of this work.

This work was aided by a grant to A.F. from the higher medicine funds of the Western Regional Hospital Board.

\section{References}

Bayless, T. M., Partin, J. S., and Partin, J. C. (1967). Serum precipitins to milk gluten and mice in tropical sprue. Bull. Johns Hopk. Hosp., 120, 310-316.

Beckwith, A. C., and Heiner, D. C. (1966). An immunological study of wheat gluten proteins and derivatives. Arch. Biochem., 117, 239. 247.

Boyden, S. V. (1951). The adsorption of proteins on erythrocytes treated with tannic acid and subsequent hemagglutination by antiprotein sera. J. exp. Med., 93, 107-120.

Buckley, R. H., and Dees, S. C. (1969). Correlation of milk precipitins with IgA deficiency. New Engl. J. Med., 281, 465-469.

Crowle, A. J. (1958). A simplified micro double-diffusion agar precipitin technique. J. Lab. clin. Med., 52, 784-787.

Ferguson, A., and Carswell, F. (1972). Precipitins to dietary proteins in serum and upper intestinal secretions of coeliac children. Brit. med. J., 1, 75-77.

Heiner, D. C., Lahey, M. E., Wilson, J. F. Gerrard, J. W., Shwachman, H., and Khaw, K. T. (1962). Precipitins to antigens of wheat and cow's milk in celiac disease. J. Pediat., 61, 813-830.

Herbert, W. J. (1967). In Handbook of Experimental Immunology, edited by D. M. Weir, 720-744. Blackwell, Oxford.

Holland, N. H., Hong, R., Davis, N. C., and West, C. D. (1962). Significance of precipitating antibodies to milk proteins in the serum of infants and children. J. Pediat., 61, 181-195.

Huntley, C. C., Robbins, J. B., Lyerly, A. D., and Buckley, R. H. (1971). Characterization of precipitating antibodies to ruminant serum and milk proteins in humans with selective IgA deficiency. New Engl. J. Med., 284, 7-10.

Lehner, T. (1969a). Immunoglobulin estimation of blood and saliva in human recurrent oral ulceration. Arch. oral Biol., 14, 351-364.

Lehner, T. (1969b). Characterization of mucosal antibodies in recurrent aphthous ulceration and Behçet's syndrome. Archs. oral Biol., 14, 843-853.

Mancini, G., Carbonara, A. O., and Heremans, J. F. (1965). Immunochemical quantitation of antigens by single radial immunodiffusion. Immunochemistry, 2, 235-254.

Ross, S., Ferguson, S., and Watkinson, G. (1973). In preparation.

Sircus, W., Church, R., and Kelleher, J. (1957). Recurrent aphthous ulceration of the mouth: a study of the natural history, aetiology and treatment. Quart. J. Med., 26, 235-249.

Taylor, K. B., Thomson, D. L., Truelove, S. C., and Wright, R. (1961). An immunological study of coeliac disease and idiopathic steatorrhoea. Brit. med. J., 2, 1727-1731.

Taylor, K. B., and Truelove, S. C. (1961). Circulating antibodies to milk proteins in ulcerative colitis. Brit. med. J., 2, 924-929.

Taylor, K. B., Truelove, S. C., and Wright, R. (1964). Serological reaction to gluten and cow's milk proteins in gastrointestinal disease. Gastroenterology, 46, 99-108.

Thomas, H. C. (1973). In preparation. 